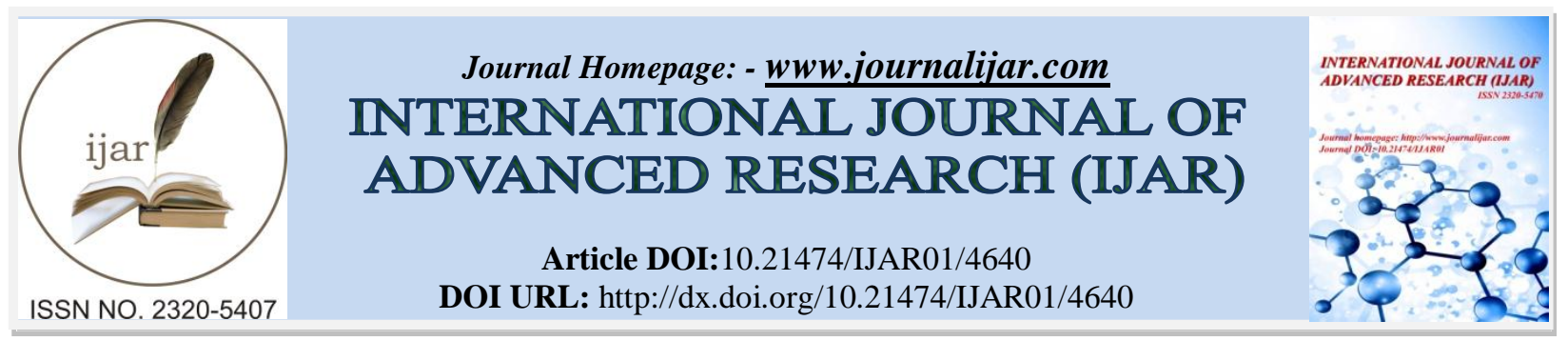

RESEARCH ARTICLE

\title{
A STUDY ON PERFORMANCE EVALUATION OF SELECTEDOPEN-ENDED EQUITY MUTUAL FUND SCHEMES IN INDIA.
}

1. Professor and Principal (Rtd.,) Jamal Mohamed College, Tiruchirappalli.

2. Ph.D Reserch Scholar in JIM and Assist Prtanofessor, Department of Business Administration, Jamal Mohamed College, Tiruchirappalli.

\section{Manuscript Info}

Manuscript History

Received: 28 April 2017

Final Accepted: 30 May 2017

Published: June 2017

Key words:-

Equity Schemes; Performance of open

ended equity Mutual Fund Schemes.

\section{Abstract}

In this paper the researcher tried to evaluate the performance of top five performed open-ended equity schemes with growth option. The period of the study spans from $1^{\text {st }}$ April 2014 to $31^{\text {st }}$ March 2017.To evaluate the performance of the selected mutual fund schemes, quarterly, half yearly and yearly wise are compared with Benchmark S\&P, CNX Nifty, BSE National 100 and SENSEX returns.

Copy Right, IJAR, 2017,. All rights reserved.

\section{Introduction of Mutual Fund:-}

A Mutual Fund is a trust that pools the savings of a number of investors who share a common financial goal. The money thus collected is then invested in capital market instruments such as shares, debentures and other securities. The income earned through these investments and the capital appreciation realised are shared by its unit holders in proportion to the number of units owned by them.

Professional Mutual Fund managers are highly experienced personnel's and act on behalf of the mutual fund company that manages the investments for the benefit of the investors in return of a management fees. The organization that manages the investment is known as Asset Management Company [AMC] In India, operations of AMC are supervised and regulated by the Securities and Exchange Board of India (SEBI).

A mutual fund is pooling money to invest more than a collection of stocks, bonds, and other securities. But the biggest advantage to mutual funds is diversification, by minimizing risk \& maximizing returns. 
Figure 1.1:- Mutual Fund Operation Flow Chart:

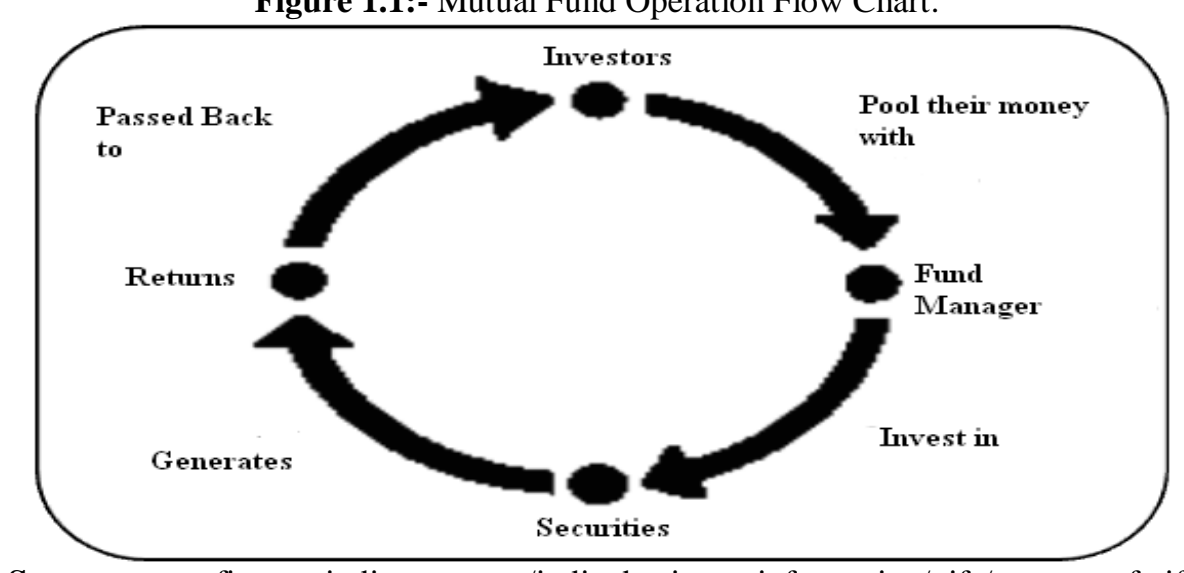

Source: www.finance.indiamart.com/india_business_information/gifs/conceptmf.gif

\section{Mutual Fund Industry In India:-}

The mutual fund industry in India started in 1963 with the formation of Unit Trust of India, at the initiative of the Government of India and Reserve Bank of India. The history of mutual funds in India can be broadly divided into four distinct phases.

First Phase - 1964-1987:-

Unit Trust of India (UTI) was established in 1963 by an Act of Parliament. It was set up by the Reserve Bank of India and functioned under the Regulatory and administrative control of the Reserve Bank of India. In 1978 UTI was de-linked from the RBI and the Industrial Development Bank of India (IDBI) took over the regulatory and administrative control in place of RBI. The first scheme launched by UTI was Unit Scheme 1964.

\section{Second Phase - 1987-1993 (Entry of Public Sector Funds):-}

1987 marked the entry of non-UTI, public sector mutual funds set up by public sector banks and LIC and GI). SBI Mutual Fund was the first non-UTI Mutual Fund established in June 1987 followed by Can bank Mutual Fund (Dec 87), Punjab National Bank Mutual Fund (Aug 89), Indian Bank Mutual Fund (Nov 89), Bank of India (Jun 90), Bank of Baroda Mutual Fund (Oct 92). LIC established its mutual fund in June 1989 while GIC had set up its mutual fund in December 1990.

Third Phase - 1993-2003 (Entry of Private Sector Funds):-

With the entry of private sector funds in 1993, a new era started in the Indian mutual fund industry, giving the Indian investors a wider choice of fund families. Also, 1993 was the year in which the first Mutual Fund Regulations came into being, under which all mutual funds, except UTI were to be registered and governed. The erstwhile Kothari Pioneer (now merged with Franklin Templeton) was the first private sector mutual fund registered in July 1993. The 1993 SEBI (Mutual Fund) Regulations were substituted by a more comprehensive and revised Mutual Fund Regulations in 1996. The industry now functions under the SEBI (Mutual Fund) Regulations 1996. The number of mutual fund houses went on increasing, with many foreign mutual funds setting up funds in India and also the industry has witnessed several mergers and acquisitions.

\section{Fourth Phase - since February 2003:-}

In February 2003, following the repeal of the Unit Trust of India Act 1963 UTI was bifurcated into two separate entities. One is the Specified Undertaking of the Unit Trust of India with assets under management of Rs. 29,835 crores as at the end of January 2003, representing broadly, the assets of US 64 scheme, assured return and certain other schemes. The Specified Undertaking of Unit Trust of India, functioning under an administrator and under the rules framed by Government of India and does not come under the purview of the Mutual Fund Regulations.

\section{Types Of Mutual Fund Schemes:-}

Wide varieties of Mutual Fund Schemes exist to cater to the needs such as financial position, risk tolerance and return expectations etc. The table below gives an overview into the existing of schemes in the Industry. 
Figure 1.4: Types of Mutual Fund Schemes:

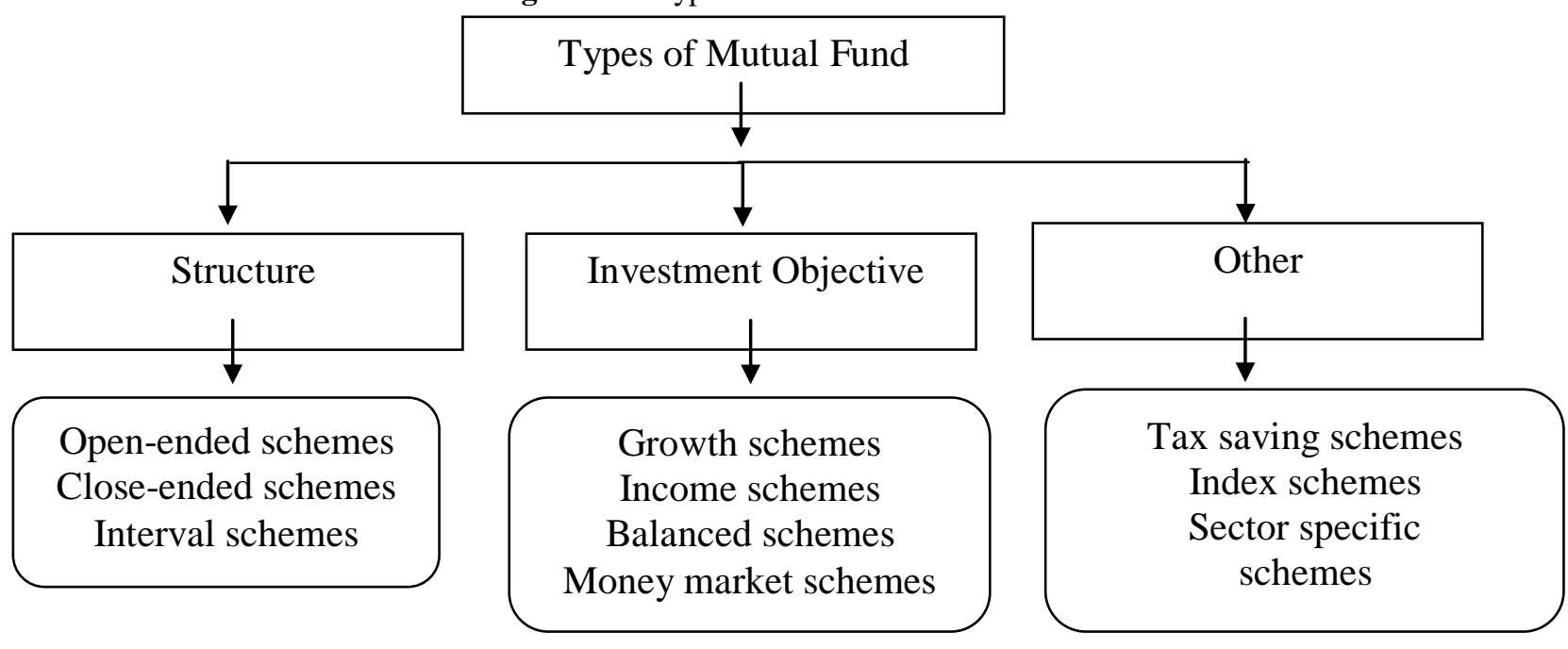

\section{Structure Based Schemes:-} Open-ended Schemes:-

These have no fixed maturity period. Open-ended schemes are available for subscription and redemption (purchase and sale) on an ongoing basis. The units are bought and sold at NAV related prices.

\section{Close-ended Schemes:-}

These schemes have stipulated maturity period. Typically, you can invest in them for between 3 to 10 years. These schemes are open for subscription only during a specified period at the time of their launch, thereafter units of the scheme can be bought or sold on the stock exchange where the scheme is listed.

\section{Interval Schemes:-}

Interval schemes are a combination of open-ended and close-ended schemes. These schemes remain open for sale and repurchase only during a specified period.

\section{Objectives Based Schemes:-}

Growth Schemes:-

Growth schemes are designed to provide optimum returns through capital appreciation over medium to long term. Major parts of their fund are invested in equities.

\section{Income Schemes:-}

If you are looking for regular and steady returns go for income schemes. These schemes generally invest in fixed income securities such as bond and corporate debentures.

\section{Balanced Schemes:-}

Balanced funds give you the best of growth and income schemes. A balanced fund invests both in equities and fixed income securities. Their returns are generally less volatile as compared to pure equity fund.

\section{Liquid Schemes:-}

Liquid schemes are also known as money market schemes. These schemes generally invest in safer short-term instruments such as treasury bills, certificated of deposit, commercial paper and government securities.

\section{Other Schemes:-}

Tax Saving Schemes:-

If you are investing because you want to save tax, go for these schemes. They offer deduction from gross total income to the investors, at present, under Sec. $80 \mathrm{C}$ of the Income Tax Act. 


\section{Special Schemes:-}

Index Funds:-

Index Funds replicate the portfolio index such as the BSE Sensitive Index, S\&P NSE 50 Index (NIFTY), etc. These schemes invest in the securities in the same weightage comprising of an index.

\section{Sector Specific Funds:-}

Sector specific funds take advantage of the boom or expected upturn in a particular industry or sector by investing in them.

\section{Literature Review:-}

Literature on mutual fund performance evaluation is enormous. A few research studies that have influenced the preparation of this paper substantially are discussed in this section.

Mishra, et al.,(2002) measured mutual fund performance using lower partial moment. In this paper, measures of evaluating portfolio performance based on lower partial moment are developed. Risk from the lower partial moment is measured by taking into account only those states in which return is below a pre-specified "target rate" like risk-free rate. Kshama Fernandes(2003) evaluated index fund implementation in India. In this paper, tracking error of index funds in India is measured.

Dr. K Ravichandran in his Research Article titled "A study on Investors preference towards various Derivatives market, published in the Journal of Contemporary Research in Management a Quarterly journal, Vol3, Sept.-2012. The objective of the study was to know the various investment avenues and the investors risk preference towards it and to find out the preference level of investors on various capital market instruments. The research article found few things like; $44 \%$ of investors are between age group of $31-40$, and they are influenced by their friend and relatives. It is concluded with the point that, though the stock market is subjected to high risk, by using derivatives the loss can be minimized to an extent.

\section{Rama Devi.V and Nooney Lenin Kumar (2009):-}

This study conducted to compare the performance of Indian and foreign equity mutual funds, to examine the performance of different equity mutual fund schemes on the basis of risk-return parameters and to investigate the performance of Indian and foreign equity mutual fund schemes on risk-adjusted measures. So this study found that the objectives of the study had been significant based on the hypothesis ${ }^{4}$.

SathyaSwaroopDebasish. (2009):-

In this study, an attempt had been made to the performance of selected schemes of mutual funds based on risk-return relationship models and measures. A total of 23 schemes offered by six private sector mutual funds and three public sector mutual funds have been studied over the time period April 1996 to March 2009 (13 years). The analysis had been made on the basis of mean return, beta risk, and coefficient of determination, Sharpe ratio, Treynor ratio and Jensen Alpha. The overall analysis found Franklin Templeton and UTI being the best performers and Birla Sun life, HDFC and LIC mutual funds showing poor below-average performance when measured against the risk-return relationship models.

RaheelGohar, Sohail Ahmed, and Urfa Niazi. (2009):-

This study was conducted to analyze and compare the performance of different types of mutual funds in Pakistan, and concluded that equity funds outperform income funds. These funds are further classified into broker backed and institutional backed funds for detail analysis. Findings showed that within equity funds, broker backed category showed better performance than institutional funds. On the other hand, among income funds, institutional funds are outperforming broker backed funds. This study further concludes that equity fund managers possess significant market timing ability and institutions funds managers are able to time their investments, but brokers operated funds did not show market timing ability ${ }^{10}$.

1. Dr.V.Rama Devi, Nooney Lenin Kumar (2009) "Performance Evaluation: A Comparative Study Between Indian and Foreign Equity Mutual Funds"TheIndianjournalof finance June,2010.

2. SathyaSwaroopDebasish.(2009) "Investicating Performance of Equity-Based Mutual Fund Schemes in Indian Scenario"SSRN.Com.

3. RaheelGohar, Sohail Ahmed, And Urfa Niazi. (2009)."Performance Comparison of Mutual Funds in Pakistan"VSRD African Journal of Business Management Vol.5 (14), 2011. 


\section{Scope of The Study:-}

The scope of the study objective is to investigate the return on investment in share market and to understand the fund sponsor qualities influencing the selection of MF Schemes. Also to find out that how far the mutual fund schemes are able to win the confidence of the investors. The researcher's study is considering the three years performance of the mutual fund schemes in India. Now, the researcher study purpose is to know the return on investment in share market and the mutual fund schemes. The research was carried out to define how investor should invest in terms of making right choice of investment in best MF schemes, in addition which techniques should be used so that they can get the better returns from the markets. For conducting the study help of certain tools were taken such as journals and Market Information from Online.

\section{Objectives of the Study:-}

- To appraise the performance of mutual fund industry in India under the regulated environment.

- To analyze the trends in returns of selected mutual funds schemes.

- To identify the best mutual fund schemes in selected periods

\section{Hypothesis:-}

Ho: There is no significant difference in performance of various Mutual Fund schemes with special reference to Level of Return.

\section{Limitations of the Study:-}

- Since the study is mostly based on the secondary data, the shortcomings of the use of secondary data are inevitable.

- Time is short to conduct the study and best schemes only six schemes has been taken for analysis.

- Sample size is too small.

Research Methodology and Some Basic Concepts:-

In this study twenty six open ended Equity mutual funds schemes have taken in top fund houses. To measure the comparative performance BSE, CNX and NIFTY has taken as benchmarks. Secondary data has been used in this study. NAV of mutual funds has been taken from the website of Mutual fund India. Data regarding top performance of open ended Equity mutual funds schemes with issued dividend by the study period.

\section{The techniques of Analysis:-}

\section{Sampling Design:-}

Universe:-

The universe of the study consists of the all the assets management companies (AMC), included selected open ended - equity mutual fund schemes under the different objective of the study.

\section{Sampling Unit:-}

The sample unit included Open ended -Equity Schemes. which are the funds provided continuous dividend in top six Schemes.

\section{Source List:-}

Sample should collection secondary sources.

\section{Sample Period:-}

Sample study should take from period 1st April 2014 to 31st March 2017.

\section{Sample Size:-}

Sample size is top six schemes from Schemes from six fund houses.

\section{Data Collection:-}

This study is completely based on the secondary data. This data is collected from various source specially from the journal - Mutual Funds-Insight- based on Value Research Magazines of the mutual funds have been consider in their search. 
Financial Tool:-

Rate of return method:- $\mathbf{R}=(\mathbf{P 1}-\mathrm{P0}+\mathrm{D1}) / \mathrm{P0}$ :-

Analysis And Interpretation:-

Table 1:- List of Mutual Funds Schemes Studied

\begin{tabular}{|l|c|c|c|}
\hline \multicolumn{1}{|c|}{ LARGE CAP SCHEMES } & $\begin{array}{c}\text { Crisil } \\
\text { Rank }\end{array}$ & $\begin{array}{c}\text { NAV } \\
\text { (Rs./Unit) }\end{array}$ & $\begin{array}{c}\text { AUM } \\
\text { (Rs. cr.)Mar 17 }\end{array}$ \\
\hline ICICI Pru Top 100 Fund (G) & Rank 1 & 295.52 & $1,546.32$ \\
\hline ICICI Pru Top 100 Fund - Direct (G) & Rank 1 & 307.07 & 234.28 \\
\hline Kotak Select Focus Fund - Direct (G) & Rank 1 & 31.64 & $1,910.64$ \\
\hline Kotak Select Focus Fund - Regular (G) & Rank 1 & 30.34 & $6,335.80$ \\
\hline SBI Blue Chip Fund (G) & Rank 1 & 35.00 & $8,582.51$ \\
\hline SBI Blue Chip Fund - Direct (G) & Rank 1 & 36.37 & $2,813.95$ \\
\hline
\end{tabular}

Different scheme launch in different dates therefore, for the purpose performance assessment the period covers $1^{\text {st }}$ April, 2014 to $31^{\text {st }}$ March, 2017.

Table 2:- Quarterly, half yearly and yearly wise Earned By the Schemes

\begin{tabular}{|l|c|c|c|c|c|}
\hline \multirow{2}{*}{\multicolumn{1}{c|}{ LARGE CAP SCHEMES }} & \multicolumn{5}{c|}{ RETURNS } \\
\cline { 2 - 6 } & Quarterly & Half Yearly & 1 Year & 2 Year & 3 Year \\
\hline ICICI Pru Top 100 Fund (G) & 2.8 & 16.6 & 22.5 & 25.1 & 39.4 \\
\hline ICICI Pru Top 100 Fund - Direct (G) & 3.2 & 17.3 & 24.0 & 27.6 & 43.4 \\
\hline Kotak Select Focus Fund - Direct (G) & 7.3 & 25.2 & 27.5 & 36.0 & 76.9 \\
\hline Kotak Select Focus Fund - Regular (G) & 7.0 & 24.5 & 26.0 & 33.0 & 71.5 \\
\hline SBI Blue Chip Fund (G) & 5.4 & 19.1 & 17.6 & 22.2 & 56.8 \\
\hline SBI Blue Chip Fund - Direct (G) & 5.7 & 19.8 & 18.9 & 25.0 & 61.5 \\
\hline
\end{tabular}

Table 2 shows the average return earned by the various schemes. For calculation of average return earned by the schemes Growth in the value for each quarterly, Half yearly and yearly wise over the previous value has been divided by the value of the previous value. Then the average of the full series has been taken. In schemes all the sample schemes had shown the highest return earners as against S\& P, Nifty and BSE 100 return (0.011384) except one i.e. Kotak Select Focus Fund - Direct (G), performed quarterly, Half yearly, one year, two years and three years wise are give return for 7.3\%, 25.2\%, 27.5\%, 36.0\% and 76.9\% respectively. Kotak Select Focus Fund - Regular (G) performed quarterly, Half yearly, one year, two years and three years wise are give return for $7.0 \%, 24.5 \%, 26 \%$, $33.0 \%$ and $71.5 \%$ respectively, Kotak Select Focus Fund - Direct (G), performed quarterly, Half yearly, one year, two years and three years wise are give return for 7.3\%, 25.2\%, 27.5\%, 36.0\% and 76.9\% respectively, Kotak Select Focus Fund - Regular (G) performed quarterly, Half yearly, one year, two years and three years wise are give return for 7.0\%, 24.5\%, 26\%, 33.0\% and 71.5\% respectively, SBI Blue Chip Fund - Direct (G) performed quarterly, Half yearly, one year, two years and three years wise are give return for $5.7 \%, 19.8 \%, 18.9 \%, 25.0 \%$ and $61.5 \%$ respectively, SBI Blue Chip Fund (G) performed quarterly, Half yearly, one year, two years and three years wise are give return for 5.4\%, 19.1\%, 17.6\%, 22.2\% and 56.8\% respectivel, ICICI Pru Top 100 Fund - Direct (G) performed quarterly, Half yearly, one year, two years and three years wise are give return for 3.2\%, 17.3\%, 24.0\%, 27.6\% and 43.4\% respectively and ICICI Pru Top 100 Fund (G) performed quarterly, Half yearly, one year, two years and three years wise are give return for $2.8 \%, 16.6 \%, 22.5 \%, 25.1 \%$ and $39.4 \%$ respectively .

Table 3:- Quarterly, half yearly and yearly wise Earned By the Schemes

\begin{tabular}{|c|c|c|c|c|}
\hline $\begin{array}{l}\text { LARGE CAP } \\
\text { SCHEMES }\end{array}$ & $\begin{array}{c}\text { Top } \\
5 \text { Holdings }\end{array}$ & $\begin{array}{c}\text { Weightage } \\
\text { ForHoldings }\end{array}$ & $\begin{array}{c}\text { Top } 3 \\
\text { Sectors }\end{array}$ & $\begin{array}{l}\text { Weightage } \\
\text { ForSectors }\end{array}$ \\
\hline $\begin{array}{l}\text { ICICI Pru Top } 100 \\
\text { Fund }(G)\end{array}$ & \multirow{2}{*}{$\begin{array}{l}\text { ICICI Bank, Bharti Airtel, } \\
\text { Power Grid Corp, Tata } \\
\text { Steel, Tata Chemicals }\end{array}$} & \multirow[t]{2}{*}{$27.9 \%$} & \multirow{2}{*}{$\begin{array}{l}\text { Banking/Finance, } \\
\text { Technology, } \\
\text { Metals \& Mining }\end{array}$} & \multirow[t]{2}{*}{$37.41 \%$} \\
\hline $\begin{array}{l}\text { ICICI Pru Top } 100 \\
\text { Fund - Direct }(\mathrm{G})\end{array}$ & & & & \\
\hline $\begin{array}{l}\text { Kotak Select Focus } \\
\text { Fund - Direct (G) }\end{array}$ & \multirow{2}{*}{$\begin{array}{l}\text { HDFC Bank, ITC, } \\
\text { Reliance, Hero Motocorp, } \\
\text { Maruti Suzuki }\end{array}$} & \multirow[t]{2}{*}{$21.98 \%$} & \multirow{2}{*}{$\begin{array}{l}\text { Banking/Finance, } \\
\text { Oil \& Gas, } \\
\text { Automotive }\end{array}$} & \multirow[t]{2}{*}{$53.72 \%$} \\
\hline $\begin{array}{l}\text { Kotak Select Focus } \\
\text { Fund - Regular (G) }\end{array}$ & & & & \\
\hline
\end{tabular}




\begin{tabular}{|l|l|l|l|l|}
\hline $\begin{array}{l}\text { SBI Blue Chip Fund } \\
\text { (G) }\end{array}$ & $\begin{array}{l}\text { HDFC Bank, Larsen, } \\
\text { M\&M, Infosys, UPL }\end{array}$ & $22.52 \%$ & $\begin{array}{l}\text { Banking/Finance, } \\
\text { Automotive, } \\
\text { Engineering }\end{array}$ & $45.54 \%$ \\
\cline { 1 - 3 } $\begin{array}{l}\text { SBI Blue Chip Fund - } \\
\text { Direct (G) }\end{array}$ & & & \\
\hline
\end{tabular}

Table 3 shows ICICI Pru Top 100 Fund - Direct (G) andICICI Pru Top 100 Fund (G) have been major holdings for these concerns ICICI Bank, Bharti Airtel, Power Grid Corp, Tata Steel, Tata Chemicals to get return 27.9\% and these were return $37.41 \%$ based on this sectors Banking/Finance, Technology, Metals \& Mining.

Kotak Select Focus Fund - Regular (G) andKotak Select Focus Fund - Direct (G) have been major holdings for these HDFC Bank, ITC, Reliance, Hero Motocorp, Maruti Suzuki to get return 21.98\% and these were return $53.72 \%$ based on this sectors Banking/Finance, Oil \& Gas, Automotive.

SBI Blue Chip Fund (G) andSBI Blue Chip Fund - Direct (G) have been major holdings for these HDFC Bank, Larsen, M\&M, Infosys, UPL to get return $22.52 \%$ and these were return $45.54 \%$ based on this sectors Banking/Finance, Automotive, Engineering.

\section{Conclusion:-}

This study concluded major top six schemes were invested similar sectors and similar holding with little bit difference. ICICI Pru Top 100 Fund - Direct (G) and ICICI Pru Top 100 Fund (G) are $3^{\text {rd }}$ place in sector wise and $1^{\text {st }}$ Place in holding wise, if they going to invest Automotive sector also, they may get good retrun. Kotak Select Focus Fund - Regular (G) andKotak Select Focus Fund - Direct $(G)$ are $1^{\text {st }}$ Place in sector wise and $3^{\text {rd }}$ place in holding wise, if they were keep few metal, technology and mining wise holdings - they may get higher return as well as sector and holding basis.SBI Blue Chip Fund $(G)$ andSBI Blue Chip Fund - Direct (G)are $2^{\text {nd }}$ Place in sector and holding wise, if they were keep few metal, technology and mining wise holdings - they may get higher return as well as sector and holding basis. But the return basis Kotak Select Focus Fund - Direct (G) for very highest return, Kotak Select Focus Fund - Regular $(G)$ for second highest return, SBI Blue Chip Fund - Direct $(G)$ for third highest return, SBI Blue Chip Fund (G) for fourth highest return, ICICI Pru Top 100 Fund - Direct (G) for fifth highest return and ICICI Pru Top 100 Fund $(G)$ for sixth highest return. These schemes were given good return for their investors.

\section{References:-}

1. Gupta, Amitabh. Mutual Funds in India - A study of Investment Management, Anmol Publication Pvt. Ltd. New Delhi. 2002.

2. Gupta, O.P. and Sehagal S. (2000), "Investment Performance of Mutual Funds: The Indian Experience", In Indian Capital Markets: Trends and Dimensions edited by UMA Shashikant and Arumugam, Tata McGraw Hill, New Delhi.

3. India.

4. Jayadev M. (1996)' "Mutual Fund Performance; an Analysis of Monthly Returns", Finance India, Vol. X, No.1, (March), Page No.73-84

5. Jayadev M. (1998), "Performance Evaluation of Portfolio Managers: An Empirical Evidence on Indian Mutual Funds", Applied Finance Vol.5, No.2, July.

6. Kumar, Vikas, Mutual Funds in India: Growth and Performance. ERT Publication, Pvt.Ltd. Varanasi, 2012.

7. Mishra B, (2001), "A study of Mutual Funds in India", UN published Research paper under the aegis of Faculty of Management Studies, University of Delhi.

8. Rao K.V. and Venkateshwarlu, K. (1998), “ Market Timing Abilities of Fund Managers-A case Study of Unit Trust of India", A paper presented at the Second Capitla Market Conference Organised by UTI Institute Capital Market, Mumbai.

9. Sadhak H, (1997) "Mutual Fund Investment and Market Practices in India", Sage Publication

10. Sethu, G. (2001),'The Mutual Fund Puzzle" in Indian Capital Markets: Modern perspective and Empirical Evidence, Allied Publishers Mumbai.

11. Singh, H.K. and Singh, Meera, 'Mutual funds and Indian capital market, performance and profitability'.

\section{Websites:-}

- www.amfi.com

- www.bseindia.com 
- www.investopedia.com

- www.moneycontrol.com

- www.reliance mf.com

- www.sebi.gov.in 